\title{
HAK PENGELOLAAN PERAIRAN PESISIR DALAM UNDANG-UNDANG NOMOR 1 TAHUN 2014 TENTANG PERUBAHAN ATAS UNDANG-UNDANG NOMOR 27 TAHUN 2007 TENTANG PENGELOLAAN WILAYAH PESISIR DAN PULAU-PULAU KECIL
}

\author{
Indra Lorenly Nainggolan ${ }^{1}$, Lazarus Tri Setyawanta ${ }^{2}$
}

\begin{abstract}
Abstrak
Penelitian ini bertujuan untuk mengkaji dan menganalisis perubahan hak menjadi konsep izin dalam UU No. 1 Tahun 2014. Metode yang digunakan dalam penelitian ini adalah yuridis normatif yang menganalisis peraturan perundang-undangan yang dikonsepsikan sebagai aturan-aturan yang telah diterima sebagai aturan yang sah karena dikeluarkan oleh lembaga yang berwenang. Berdasarkan hasil penelitian bahwa prinsip hak dalam mengelola wilayah pesisir dan pulau-pulau kecil, menempatkan HP-3 sebagai hak kebendaan. Ketentuan hak sebagai hak kebendaan dan izin adalah sama, artinya semua hak itu memerlukan izin, sehingga pengaturan tentang IP-3 dan HP-3 hakikatnya sama, hanya pembalikan kata saja, yang terpenting adalah substansi bentuk perizinan tersebut. Konsep IP-3 tidak mewajibkan masyarakat hukum adat dalam pemanfaatan sumber daya pesisir dan pulau-pulau kecil untuk memiliki IP-3. Akan tetapi, IP-3 yang diatur dalam perubahan UU No. 27 Tahun 2009 masih memberikan peluang besar dan menfasilitasi pemilik modal untuk menguasai pesisir laut dan pulau-pulau kecil. Keberadaan masyarakat wilayah pesisir dan pulau-pulau kecil masih menjadi pihak yang lemah atas keberadaan korporasi tersebut.
\end{abstract}

Kata kunci: Perubahan Ketentuan Hak, Pengelolaan Pesisir, UU No. 1 Tahun 2014

\section{A. Latar Belakang}

Pengelolaan wilayah pesisir dan pulau-pulau kecil dalam UU No.27 Tahun 2007 tentang Pengelolaan Wilayah Pesisir dan Pulau-Pulau Kecil (UU PWP-PPK) wajib memiliki HP-3 (Hak Pengelolaan Perairan Pesisir). HP-3 sebagai alas hak dalam pengelolaan wilayah pesisir, merupakan hak atas bagian-bagian tertentu dari perairan pesisir untuk usaha kelautan dan perikanan, serta usaha lain yang terkait dengan pemanfaatan sumber daya pesisir dan pulau-pulau kecil yang mencakup atas permukaan laut dan kolom air sampai dengan permukaan dasar laut pada batas

1 Mahasiswa Program Studi Magister Ilmu Hukum UNDIP

2 Dosen Program Studi Magister Ilmu Hukum UNDIP 
keluasan tertentu (Pasal 1 angka 18 UU PWP-PPK). Kenyataannya, bahwa ketentuan HP-3 pada tahapan kegiatan pemanfaatan yang diatur UU PWP-PPK ternyata justru menimbulkan pertentangan dari kalangan masyarakat wilayah pesisir karena keberadaan HP-3 dianggap telah melemahkan masyarakat wilayah pesisir khususnya masyarakat hukum adat dalam memanfaatkan sumberdaya wilayah pesisir dan pulau-pulau kecil.

Kemudian, UU PWP-PPK dimintakan judicial review ke MK. MK pun membatalkan beberapa pasal terkait pengaturan HP-3 dalam UU PWP-PPK. Akibatnya, ketentuan HP-3 diganti menjadi IP-3 (Izin Pengelolaan Perairan Pesisir) dalam UU No.1 Tahun 2014 tentang Perubahan Atas UU No.27 Tahun 2007 tentang Pengelolaan Wilayah Pesisir Dan Pulau-Pulau Kecil, dikarenakan telah terjadi kekosongan hukum dalam pengelolaan wilayah pesisir dan pulau-pulau kecil pasca putusan MK. Oleh karena itu, perubahan hak menjadi konsep izin dalam UU No.1 Tahun 2014 perlu dikaji, agar keberadaan konsep IP-3 tidak hanya sekedar ganti konsep dari yang terdahulunya, akan tetapi agar dapat mempertahankan keberadaan masyarakat wilayah pesisir khususnya masyarakat hukum adat atas akses pemanfaatan sumberdaya wilayah pesisir dan pulau-pulau kecil yang menjadikan hak-hak mereka terlindungi guna kesejahteraannya.

\section{A. Metode Penelitian}

Penelitian ini bersifat normatif yang memiliki tujuan untuk menganalisis peraturan perundang-undangan yang dikonsepsikan sebagai aturan-aturan yang telah diterima sebagai aturan yang sah karena dikeluarkan oleh lembaga yang berwenang. Data yang dikaji adalah data sekunder yang berupa bahan-bahan hukum yaitu bahan 
hukum primer dan bahan hukum sekunder dan jenis penelitian ini termasuk dalam jenis penelitian kepustakaan (library research) yang disajikan secara deskriptif.

\section{B. Hasil dan Pembahasan}

\section{Pembatalan Konsep HP-3 Dalam Putusan MK Nomor 3/PUU-VIII/2010}

MK dalam putusannya Nomor 3/PUU-VIII/2010 telah membatalkan Pasal 1 angka 18, Pasal 16, Pasal 17, Pasal 18, Pasal 19, Pasal 20, Pasal 21, Pasal 22, Pasal 23 ayat (4), (5), Pasal 50, Pasal 51, Pasal 60 ayat (1), Pasal 71, dan Pasal 75. Beberapa pasal yang dibatalkan tersebut merupakan ketentuan yang mengatur keberadaan HP-3. MK berpendapat bahwa prinsip hak dalam mengelola wilayah pesisir dan pulau-pulau kecil, menempatkan HP-3 sebagai hak kebendaan.

Penting dipahami bahwa keberadaan hak mutlak sebagai hak kebendaan harus dibedakan dengan hak mutlak sebagai hak pokok dasar manusia. Hak pokok dasar manusia merupakan hak alami yang melekat bagi setiap subyek hukum (manusia) sejak ia dilahirkan, sedangkan hak kebendaan harus ada tindakan dari subyek hukum untuk memilikinya. Van Apeldoorn, menyatakan hak adalah kekuasaan (wewenang) yang oleh hukum diberikan kepada seseorang (atau suatu badan hukum), dan yang menjadi tantangannya adalah kewajiban orang lain (badan hukum lain) untuk mengakui kekuasaan itu. ${ }^{3}$ Sedangkan C.S.T. Kansil ${ }^{4}$ mengatakan bahwa dalam hukum seseorang yang mempunyai hak milik atas sesuatu benda kepadanya diizinkan untuk menikmati hasil dari benda miliknya itu. Izin atau kekuasaan yang diberikan hukum itu disebut hak atau wewenang.

3 Marwan Mas, 2011, Pengantar IImu Hukum, Bogor, Ghalia Indonesia, hlm 30.

4 C.S.T. Kansil dan Christine S.T.Kansil, 2008, Pengantar IImu Hukum J ilid I, Jakarta, Balai Pustaka, hlm 87. 
Hak kebendaan sebagaimana dimaksud oleh MK adalah berbeda dengan hak mutlak sebagai hak pokok dasar manusia, sehingga HP-3 dalam UU PWP-PPK berbeda dengan hak mutlak sebagai hak pokok dasar manusia, dan HP-3 merupakan hak kebendaan yang akan lahir atas upaya permintaan dari subyek hukum dan timbulnya hak atas petunjuk perundang-undangan. Bagi mereka yang telah memiliki HP-3 sebagaimana diatur, maka dengan sendirinya selama kurun waktu yang ditentukan dalam HP-3, mutlak haknya dapat dipertahankan oleh hukum dan orang lain wajib untuk tidak mengganggu hak tersebut. Ketika ada yang mengganggu HP-3 tersebut, maka hukum menyediakan tempat bagi pemilik HP-3 untuk mengajukan gugatan. Secara prinsipil juga, ketika dalam HP-3 kemudian dibebankan dengan hak yang lain oleh sipemilik HP-3, maka dengan sendirinya hak yang mengikutinya tetap di bawah hak yang utama. Karena bagaimanapun juga hak yang utama dalam HP-3 menjadi istimewa dan hak yang mengikutinya memiliki keterbatasan dari hak yang sebelumnya.

HP-3 memiliki hubungan kepemilikan dengan si pemilik HP-3. Pemilik HP-3 dapat bebas memanfaatkan objek yang di atur dalam HP-3 tersebut seperti memanfaatkan nilai ekonomis yang terkandung dalam objek HP-3. Dalam konteks praktik hukum kebendaan, maka ciri-ciri dari HP-3 tersebut akan melahirkan sebuah privatisasi terhadap objek sumberdaya wilayah pesisir dan pulau-pulau kecil. Privatisasi ini tidak dapat dihindarkan karena UU PWP-PPK dengan konsep open acces, pengelolaannya tidak bersandarkan pada masyarakat wilayah pesisir. Dengan begitu bentuk pengelolaan wilayah pesisir dan pulau-pulau kecil hanya dikuasai oleh perorangan atau swasta yang memiliki modal. Hal ini semakin benar 
jika diperhatikan keberadaan Pasal 23 ayat (7) yang menyatakan bahwa pemanfaatan pulau-pulau kecil dan perairan di sekitarnya dapat juga diberikan kepada orang asing dengan persetujuan Menteri.

Wilayah pesisir dan pulau-pulau kecil dikuasai oleh negara dan dipergunakan sebesar-besarnya untuk kemakmuran rakyat. Secara yuridis konsep dasar hak menguasai sumberdaya wilayah pesisir dan pulau-pulau kecil termuat dalam Pasal 33 ayat 3 UUD 1945, yang berbunyi: Bumi dan air dan kekayaan alam yang terkandung di dalamnya dikuasai oleh negara dan dipergunakan untuk sebesar-besar kemakmuran rakyat. MK berpendapat bahwa pengertian prinsip "dikuasai oleh negara" hanya diartikan sebagai pemilikan dalam arti perdata (privat) oleh negara, maka tidaklah mencukupi untuk mencapai tujuan "sebesar-besar kemakmuran rakyat", sehingga amanat untuk "memajukan kesejahteraan umum" dan "mewujudkan suatu keadilan sosial bagi seluruh rakyat Indonesia" dalam Pembukaan UUD 1945 tidak mungkin dapat diwujudkan. Dengan demikian, istilah dikuasai oleh negara haruslah diartikan mencakup makna penguasaaan oleh negara dalam arti luas yang bersumber dan berasal dari konsepsi kedaulatan rakyat Indonesia atas segala sumber kekayaan "bumi dan air dan kekayaan alam yang terkandung di dalamnya", termasuk pula di dalamnya kepemilikan publik oleh kolektivitas rakyat atas sumber-sumber kekayaan dimaksud.

Jimly Asshiddiqie ${ }^{5}$ memberikan penjelasan bahwa istilah dikuasai oleh negara tidak hanya terbatas pada pengaturan, pengurusan dan pengawasan

5 Jimly Asshidiqie, 2009, Komentar Atas Undang-Undang Dasar Negara Republik Indonesia 1945, Jakarta, Sinar Graha, hlm 142. 
terhadap hak perorangan tetapi negara juga memiliki kewajiban untuk turut ambil bagian secara aktif dalam mencapai kesejahteraan rakyat. Keterlibatan negara sampai tahapan pengelolaan wilayah pesisir dan pulau-pulau kecil merupakan konsekuensi dari konsep negara kesejahteraan (welfare state) yang dimiliki bangsa ini. Dalam ajaran welfare state, ${ }^{6}$ yang merupakan bentuk konkret dari peralihan prinsip staatsonthounding, membatasi peran negara dan pemerintah untuk mencampuri kehidupan ekonomi dan sosial masyarakat, menjadi staatsbemoeienis yang menghendaki negara dan pemerintah terlibat aktif dalam kehidupan ekonomi dan sosial masyarakat, sebagai langkah untuk mewujudkan kesejahteraan umum, di samping menjaga ketertiban dan keamanan (rust en orde).

Fungsi kepengurusan oleh negara dilakukan oleh pemerintah dengan kewenangannya untuk menerbitkan dan mencabut fasilitas perijinan, lisensi, dan konsesi. Fungsi pengaturan oleh negara dilakukan melalui kewenangan legislasi dan regulasi. Fungsi pengelolaan dilakukan melalui mekanisme pemilikan saham dan/atau melalui keterlibatan langsung badan usaha milik negara, termasuk di dalamnya badan usaha milik daerah atau badan hukum milik negara/daerah sebagai instrumen kelembagaan di mana pemerintah mendayagunakan kekuasaannya atas sumber-sumber kekayaan itu untuk digunakan sebesar-besar kemakmuran rakyat. Demikian pula fungsi pengawasan oleh negara dilakukan oleh negara (pemerintah) dalam rangka mengawasi dan mengendalikan agar pelaksanaan penguasaan oleh negara atas kekayaan alam atas bumi, air, dan kekayaan alam benar-benar digunakan untuk sebesar-besar kemakmuran rakyat.

6 Ridwan, HR, 2003, Hukum Administrasi Negara , Yogyakarta, UII Press, hIm 11. 
MK dalam putusannya pun memberikan sebuah alternatif dalam pengelolaan wilayah pesisir dan pulau-pulau kecil yaitu dengan mekanisme perizinan. Dikatakan bahwa, untuk menghindari pengalihan tanggung jawab penguasaan negara atas pengelolaan perairan pesisir dan pulau-pulau kecil kepada pihak swasta, maka negara dapat memberikan hak pengelolaan tersebut melalui mekanisme perizinan. Menurut hemat penulis, keberadaan konsep hak sebagai hak kebendaan dan izin dalam ilmu hukum sebenarnya sama saja sebagaimana dikemukakan oleh para sarjana. Konsep dasar perizinan tentunya akan melahirkan sebuah hak bagi pemegang izin tersebut, sebaliknya dalam hak kebendaan, seseorang yang mempunyai hak milik atas suatu benda kepadanya diizinkan untuk menikmati hasil dari benda miliknya itu. Justru substansi pengaturan izin tersebut yang menjadi pokok terpenting, apakah menghilangkan tanggung jawab negara atas pengelolaan wilayah pesisir dan pulau-pulau kecil tersebut atau justru sebaliknya tetap saja sebagaimana diatur dalam UU PWP-PPK.

Hak dan izin sama-sama bentuk dari hak kebendaan dan bukan berarti menolak keberadaan konsep perizinan. Akan tetapi penulis ingin memberikan pemahaman bahwa suatu hak kebendaan tidak diperbolehkan melanggar hak masyarakat yang pada dasarnya dilindungi oleh konstitusi. Untuk itu keberadaan HP-3 sebenarnya tidak akan melanggar konstitusi sepanjang HP-3 tidak mengalihkan tanggung jawab negara kepada swasta dan tidak menyampingkan keberadaan masyarakat wilayah pesisir, khususnya masyarakat hukum adat dalam mengelola wilayah pesisir dan pulau-pulau kecil guna kemakmuran masyarakat pesisir. 
Menurut penulis, jika dikatakan pemerintah wajib melindungi hak-hak masyarakat adat dan masyarakat tradisional, maka akan bertentangan dengan pengaturan yang mewajibkan bagi masyarakat hukum adat dan masyarakat tradisional memiliki HP-3 atas pengelolaan wilayah pesisir dan pulau-pulau kecil. Pengaturan HP-3 bagi masyarakat hukum adat menjadi sesuatu kontradiksi dengan keberadaan masyarakat hukum adat tersebut, karena keberadaan masyarakat hukum adat yang pada dasarnya tunduk pada hak ulayat kemudian dipaksa harus tunduk pada HP-3, dengan begitu masyarakat hukum adat tidak dapat mengaplikasikan hukum adat atau hak ulayat atas pengelolaan wilayah pesisir dan pulau-pulau kecil.

\section{Konsepsi IP-3 dalam UU No.1 Tahun 2014 tentang Perubahan Atas UU} No.27 Tahun 2007 tentang Pengelolaan Wilayah Pesisir dan Pulau-Pulau Kecil

Konsep IP-3 dalam UU No.1 Tahun 2014 adalah izin yang diberikan untuk melakukan kegiatan pemanfaatan sumber daya Perairan Pesisir dan perairan pulau-pulau kecil. Di samping harus memiliki IP-3, terlebih dahulu setiap subjek hukum harus memiliki izin lokasi yang merupakan jadi dasar pemberian IP-3. Bagi setiap subyek hukum telah memiliki IP-3 dengan persyaratan tertentu, maka bagi mereka mutlak untuk menguasai obyek dari IP-3 tersebut dan tentunya dapat dipertahankan kepada siapapun juga. Artinya, ada kewajiban bagi subyek hukum lain untuk tidak memanfaatkan daerah yang diatur dalam IP-3 tersebut.

Mengikuti pertimbangan MK yang sebelumnya telah diuraikan diatas terkait HP-3 memiliki ciri-ciri hak kebendaan, maka hal yang sama juga akan ditemui 
dalam UU No.1 Tahun 2014. Pada Pasal 22 C dikatakan bahwa ketentuan lebih lanjut mengenai syarat, tata cara pemberian, pencabutan, jangka waktu, luasan, dan berakhirnya izin lokasi dan izin pengelolaan diatur dengan Peraturan Pemerintah. Itu artinya bentuk IP-3 jelas nantinya akan dikemas juga dalam ketentuan jangka waktu, luasan, dan berakhirnya izin lokasi yang diatur dalam peraturan pelaksana dibawah undang-undang.

Meski demikian dalam pasal 17 ayat 3 ditekankan bahwa nantinya keberadaan izin lokasi pasti dalam bentuk luasan dan waktu tertentu. Izin lokasi sebagai dasar pemberian IP-3 maka ketentuannya juga akan mengikuti pengaturan dalam izin lokasi, untuk itu keberadaan IP-3 nantinya akan menggunakan ketentuan luasan dan waktu tertentu juga. Bentuk dari peraturan pelaksana terkait ketentuan jangka waktu, luasan, dan berakhirnya izin lokasi adalah sifat dari hak kebendaan. Selama waktu yang ditentukan, nantinya hukum akan melindungi luasan obyek dari pemilik IP-3 tersebut.

Hasilnya, ketentuan ini sama dengan ketentuan yang diatur sebelumnya dalam pasal 17 ayat 1 UU PWP-PPK. Hanya saja pada UU PWP-PPK dijelaskan lebih lanjut dalam pasal 19 tentang jangka waktu pemakaian HP-3 untuk 20 (dua puluh) tahun dan dapat diperpanjang tahap kesatu paling lama 20 (dua puluh) tahun dan dapat diperpanjang lagi untuk tahap kedua sesuai dengan peraturan perundang-undangan, sedangkan hasil perubahannya masih menunggu pengaturan lebih lanjut dalam peraturan pelaksananya.

Selain itu, pengaturan ciri-ciri hak kebendaan yang terdapat pada UU PWP-PPK yaitu dalam pasal 20 ayat 1 tentang HP-3 yang dapat beralih, dialihkan, 
dan dijadikan jaminan utang dengan dibebankan hak tanggungan. Secara rinci kita tidak akan ditemui ketentuan ini dalam UU No.1 Tahun 2014. Akan tetapi, jika diamati unsur hak kebendaan dikenal dengan suatu tingkatan, yang diartikan hak kebendaan yang lebih tua menduduki peringkat yang lebih tinggi dari hak kebendaan yang timbul setelahnya, misalnya jika seseorang sudah memiliki hak kebendaan hak milik atas obyek benda tertentu, maka dapat dibebankan hak kebendaan yang lain untuk mengikutinya dan hak milik tersebut memiliki kedudukan yang lebih tinggi atas hak kebendaan yang mengikutinya. Mengikuti pengaturan bentuk IP-3 dengan ciri-ciri yang telah dijelaskan sebelumnya dengan sendirinya IP-3 dapat dibebankan hak kebendaan yang lain untuk mengikutinya sepanjang tidak melanggar hak kebendaannya terdahulu. Sifat hak kebendaan yang lebih tua menduduki peringkat yang lebih tinggi dari hak kebendaan yang timbul setelahnya dan bukan tidak mungkin juga dapat beralih, dialihkan, dan dijadikan jaminan utang dengan dibebankan hak tanggungan oleh sipemilik hak. Oleh karenanya, ketika IP-3 dialihkan, maka hak dari IP-3 tersebut mengikuti orang yang memilikinya.

Perbandingan dengan yang sebelumnya jika HP-3 diberikan dalam sertifikat hak, maka dalam UU No.1 Tahun 2014 tidak disebutkan mengenai bentuk IP-3 tersebut. Akan tetapi dalam praktik hukum kebendaan, ketika semua unsur-unsur permohonan izin terpenuhi, maka akan ada bentuk otentik dari perizinan tersebut yang tentunya dalam bentuk sertifikat juga. Meski demikian, substansi yang menjadi kajian selanjutnya adalah, apakah pengaturan IP-3 dalam UU No.1 Tahun 2014 menjadikan penguasaan negara atas pengelolaan wilayah pesisir dan 
pulau-pulau kecil masih dominan dan mampu memberikan kemakmuran bagi masyarakat wilayah pesisir.

Keberadaan IP-3 sebagai hak kebendaan masih cenderung keberpihakan pada pihak swasta. Kebijakan IP-3 dalam kajian UU No.1 Tahun 2014, masih belum sesuai dengan konsep pengelolaan pesisir terpadu berbasis masyarakat wilayah pesisir. Sehingga, dikhawatirkan belum dapat mensejahterakan masyarakat wilayah pesisir. Sebagaimana semangat yang terkandung dalam Keputusan Menteri Kelautan dan Perikanan No.10 Tahun 2002 tegas dinyatakan bahwa program PPT harus dilakukan secara konsisten, mulai dari tingkat Nasional, Propinsi, dan Kabupaten/Kota, serta Desa, baik secara bersamaan atau terpisah harus memberikan manfaat langsung kepada masyarakat yang ikut berperan serta guna pengelolaan sumberdaya berkelanjutan dan dapat meningkatkan kesejahteraan masyarakat sekitarnya.

Pada dasarnya tujuan yang ingin dicapai dari pengelolaan wilayah pesisir secara terpadu dilaksanakan dengan tujuan: (a) melindungi, mengonservasi, merehabilitasi, memanfaatkan, dan memperkaya sumberdaya wilayah pesisir dan pulau-pulau kecil serta sistem ekologisnya secara berkelanjutan; (b) menciptakan keharmonisan dan sinergi antara pemerintah dan pemerintah daerah dalam pengelolaan sumberdaya wilayah pesisir dan pulau-pulau kecil; (c) memperkuat peran serta masyarakat dan lembaga pemerintah serta mendorong inisiatif masyarakat dalam pengelolaan sumberdaya wilayah pesisir dan pulau-pulau kecil agar tercapai keadilan, keseimbangan, dan keberkelanjutan; dan (d) meningkatkan 
nilai sosial, ekonomi, dan budaya masyarakat melalui peran serta masyarakat dalam pemanfaatan sumberdaya wilayah pesisir dan pulau-pulau kecil.

Jelas dinyatakan bahwa peran masyarakat dan lembaga pemerintah menjadi unsur yang utama. Artinya, apabila pemerintah mengalihkan tanggungjawabnya pada pihak swasta serta peran masyarakat wilayah pesisir tidak dominan maka dengan sendirinya konsep pengelolaan wilayah pesisir terpadu tersebut tidak berbasis masyarakat wilayah pesisir. Terlebih hadirnya Pasal 26A yang masih memberikan tempat bagi pihak asing untuk mengelola sumberdaya wilayah pesisir dan pulau-pulau kecil. Keberadaan pihak asing menjadi bagian yang diperdebatkan dalam pengelolaan wilayah pesisir dan pulau-pulau kecil. Sebenarnya keberadaan masyarakat wilayah pesisir maupun koperasi yang dibentuk masyarakat dapat diberdayakan dengan baik, sepanjang pemerintah daerah masif mengelolanya, misalnya berupa pemberian modal kredit mikro pada masyarakat pesisir guna meningkatkan kesejahteraan para masyarakat pesisir.

Perubahan yang diinginkan dari UU No.1 Tahun 2014, sebenarnya menuntut masyarakat wilayah pesisir berperan aktif mulai tahap perencanaan, pemanfaatan, pengawasan dan pengendalian atas pengelolaan wilayah pesisir dan pulau-pulau kecil. Keberadaan HP-3 diubah menjadi IP-3 sebenarnya tidak menjadi permasalahan, namun penulis lebih sependapat ketika IP-3 tersebut murni dikelola oleh masyarakat wilayah pesisir, baik masyarakat adat dengan ketentuan hukum adatnya, masyarakat tradisional dan masyarakat lokal dengan perundang-undangan yang berlaku. Sementara itu pemerintah turut campur tangan dalam memberikan fasilitas dan memberdayakan masyarakat wilayah pesisir 
tersebut, agar dapat mengelola dan memanfaatkan sumberdaya wilayah pesisir dan pulau-pulau kecil yang mampu meningkatkan kesejahteraan mereka.

\section{Simpulan}

Berdasarkan hasil penelitian, maka penulis menarik kesimpulan bahwa ketentuan hak sebagai hak kebendaan dan izin adalah sama, artinya semua hak itu memerlukan izin, dalam permohonan izin akan melahirkan hak baru. Penggunaan hak sudah diakui memiliki hak diawal tapi belum berwujud, karena harus dipenuhi dengan izin, sedangkan dalam permohonan izin, setelah diajukan persyaratan izin-izin tersebut maka izin telah menjadi penting karena hak sudah didapatkan, di samping itu penggunaan izin lebih lunak. Pengaturan tentang IP-3 dan HP-3 hakikatnya sama, hanya pembalikan kata saja, yang terpenting adalah substansi bentuk perizinan tersebut.

Konsep IP-3 tidak mewajibkan masyarakat hukum adat dalam pemanfaatan sumber daya pesisir dan pulau-pulau kecil untuk memiliki IP-3. Akan tetapi IP-3 masih memberikan peluang besar dan menfasilitasi pemilik modal untuk menguasai pesisir laut dan pulau-pulau kecil. Keberadaan masyarakat wilayah pesisir dan pulau-pulau kecil masih menjadi pihak yang lemah atas keberadaan korporasi tersebut. Disisi lain, perubahan yang ada pada UU No.1 Tahun 2014 belum sepenuhnya mengikuti konsep pengembangan pengelolaan sumberdaya wilayah pesisir berbasis masyarakat. Oleh karenanya tuntutan memberikan peran aktif masyarakat wilayah pesisir dalam pemanfaatan sumberdaya pesisir dan pulau-pulau kecil dalam UU No.1 Tahun 2014 masih tidak maksimal. 


\section{Daftar Pustaka}

Asshidiqie, Jimly., 2009, Komentar Atas Undang-Undang Dasar Negara Republik Indonesia 1945, Jakarta: Sinar Graha.

C.S.T. Kansil dan Christine S.T.Kansil., 2008, Pengantar Ilmu Hukum Jilid I, Jakarta: Balai Pustaka.

HR, Ridwan., 2003, Hukum Administrasi Negara, Yogyakarta: UII Press.

Mas, Marwan., 2011, Pengantar Ilmu Hukum, Bogor: Ghalia Indonesia.

\section{Peraturan perundang-undangan:}

Undang-Undang Dasar Tahun 1945

UU No.1 Tahun 2014 tentang Perubahan Atas UU No.27 Tahun 2007 tentang Pengelolaan Wilayah Pesisir dan Pulau-Pulau Kecil.

UU No.27 Tahun 2007 tentang Pengelolaan Wilayah Pesisir dan Pulau-Pulau Kecil.

Keputusan Menteri Kelautan dan Perikanan No.10 Tahun 2002 tentang Pedoman Umum Perencanaan dan Pengelolaan Pesisir Terpadu.

Putusan MK Nomor 3/PUU-VIII/2010. 